\author{
MONIKA MARCINKOWSKA \\ Katedra Chemii Farmaceutycznej \\ Wydział Farmaceutyczny \\ Uniwersytet Jagielloński Collegium Medicum w Krakowie \\ Medyczna 9, 30-688 Kraków \\ E-mail: monika.marcinkowska@uj.edu.pl
}

\title{
STARY LEK NASENNY I JEGO SKUTECZNOŚĆ KLINICZNA W SCHORZENIACH O PODŁOŻU NEUROLOGICZNYM*
}

\section{WSTEP}

W latach 80. XX w. francuskie koncerny farmaceutyczne opracowały nowe leki nasenne, tzw. „Leki Z”: zaleplon, zolpidem i zopiklon (TERZANO i współaut. 2003). Powstały one $z$ myślac o alternatywie dla ówcześnie stosowanych leków $z$ grupy benzodiazpein, które w latach 60-70. XX w. całkowicie zdominowały farmakoterapię zaburzeń snu. Warto dodać, iż w latach 70. pochodna benzodiazepiny - diazepam, uzyskał status leku najlepiej sprzedajacego się, a zyski ze sprzedaży sięgały milion dolarów rocznie (CALCATERRA i BARROW 2014). W tamtych czasach powoli rosła świadomość zarówno klinicystów, jak i samych pacjentów odnośnie działań niepożądanych oraz ryzyka zwiazanego $z$ terapia benzodiazepinami. Pacjenci zgłaszali nadmierna senność w ciagu dnia, pogorszenie funkcji poznawczych, a także rozwój tolerancji i uzależnienia (JAMROŻY i współaut. 2009). Stało się to główna przyczyną rozpoczęcia intensywnych prac badawczych majacych na celu opracowanie nowych leków, które stanowiłyby subtelną alternatywę dla benzodiazepin. W tym celu badacze $z$ francuskich firm farmaceutycznych postanowili zastąpić klasyczny pierścień benzodiazepiny innymi ugrupowaniami heterocyklicznymi: pirolo[3,4-b]pirazyny, imidazo[1,2-a]pirydyny oraz pirazolo[1,5-a]pirymidyny (Ryc. 1), w nadziei, iż taka zamiana pozwoli zachować powinowactwo do głównego celu biologicznego, czyli receptora kwasu $\gamma$-aminomasłowego typu A (GABA-A), a nowe struktury będa cechować się zmniejszonym ryzykiem wystąpienia działań niepożądanych (TERzANo i współaut. 2003). W ten sposób na przełomie lat 80. i 90. XX w., na rynku farmaceutycznym pojawiły się nowe leki nasenne o strukturze „niebenzodiazepinowej”: zopiklon (1985, Rhone - Poulenc S.A., pochodna pirolo[3,4-b]pirazyny; COTREL i współaut. 1972), zolpidem (1987, Synthelabo, pochodna imidazo[1,2-a]pirydyny; KAPLAN i GEORGE 1983) oraz zaleplon (1999, King Pharmaceuticals, pochodna pirazolo[1,5-a]pirymidyny; DuszA i współaut. 1985).

Z pośród trzech „leków Z” najczęściej przepisywanym lekiem nasennym jest zolpidem, między innymi dlatego, że wykazuje specyficzne właściwości farmakologiczne. Zolpidem stosunkowo szybko indukuje sen, a $z$ uwagi na jego krótki okres półtrwania wynoszacy ok 2-3h u ludzi, nie wpływa na aktywność pacjentów w ciagu dnia (ARBILLA i współaut. 1985). Większość pacjentów raportuje dobre samopoczucie, bez upośledzenia funkcji poznawczych i uczucia tzw. „kaca następnego dnia”, który jest zwiazany ze stosowaniem leków $z$ grupy benzodiazepin.

Mechanizm działania zolpidemu opiera się na pozytywnej allosterycznej modulacji receptora GABA-A, czyli nasileniu efektu endogennego agonisty kwasu $\gamma$-aminomasłowego (GABA). Z kolei receptor GABA-A jest białkiem składajacym się $Z 5$ podjednostek: dwóch a (a1-6), dwóch $\beta$ (13) i jednej $\gamma$ (1-3) lub $\delta$, które tworza kanał jonowy przepuszczalny selektywnie dla jo- 
Leki „Z"

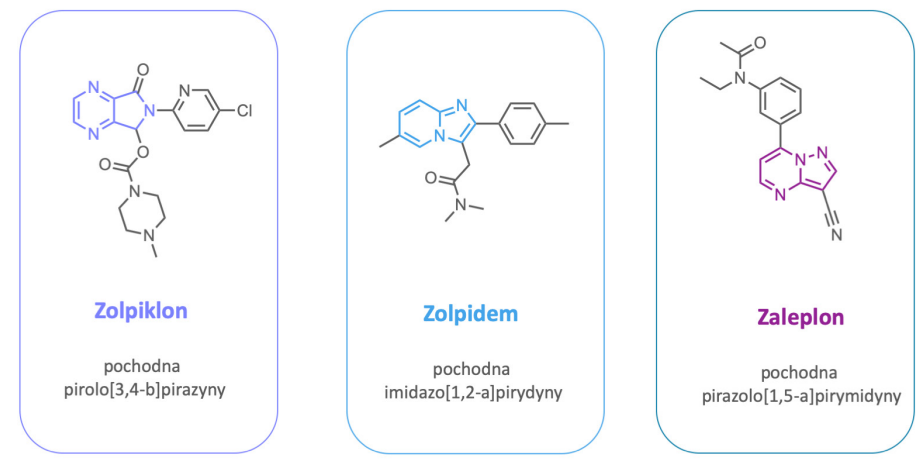

Rys 1 . Struktury chemiczne leków $Z$

nów chlorkowych (Sigel i SteinManN 2012). Zolpidem, jako ligand allosteryczny, łączy się $z$ receptorem GABA-A w innym miejscu niż naturalny agonista GABA i sam nie wywiera efektu farmakologicznego. Do wystapienia efektu farmakologicznego w przypadku modulatorów receptora GABA-A niezbędna jest obecność endogennego agonisty: GABA. Tak zaktywowany receptor GABA-A powoduje otwarcie się kanału jonowego i nasilenie przepływu jonów chlorkowych do wnętrza komórki, co powoduje hiperpolaryzację błony i w efekcie wywołuje potencjał hamujacy (ARBILlA i współaut. 1985). W przeciwieństwie do zopiklonu i zaleplonu, zolpidem łaczy się preferencyjnie $z$ subpopulacja receptorów GABA-A zawierajacych $z$ podjednostki $a_{1}$, podczas gdy jego powinowactwo do pozostałych podjednostek $a_{2} a_{3}$ jest 10 krotnie niższe, nie wiąże się $z$ receptorami $\mathrm{GABA}_{\mathrm{A}}$ zawierającymi podjednostkę $\mathrm{a}_{5}$ (SANNA i współaut. 2002). Taki profil aktywności powoduje, iż zolpidem wywiera głównie działanie nasenne w dawkach terapeutycznych.

Z uwagi na pozytywny efekt terapeutyczny, zolpidem szybko zyskał status leku najlepiej sprzedającego się w USA i Europie, a liczba sprzedanych opakowań rosła progresywnie od momentu pierwszej rejestracji w Europie i USA. Według raportu Europejskiej Agencji Leków ( $z$ ang. European Medicines Agency, EMA) w 2012 r. odnotowano około 1 miliona zaordynowanych recept na zolpidem we Francji i Wielkiej Brytanii (EMA 2013). W USA, Amerykańska Agencja Żywności i Leków $(z$ ang. Food and Drug Administration, FDA) w 2011 r. zarejestrowała ponad 39 milionów recept na zolpidem (HARWARD i współaut. 2015). Te wysokie liczby pokazuja, jak dużym problemem jest bezsenność, która jednak funkcjonuje nie tylko jako pojedyncze schorzenie, ale towarzyszy pacjentom $z$ różnymi chorobami współistniejacymi, takimi jak: choroba Parkinsona, zaburzenia o podłożu neurologicznym czy choroby psychiczne. Na początku 2000 r. w literaturze medycznej odnotowano kilka zadziwiających przypadków dotyczących niespotykanych właściwości farmakologicznych zolpidemu.

\section{EFEKTY ZOLPIDEMU U PACJENTÓW Z CHOROBA PARKINSONA}

Choroba Parkinsona to schorzenie neurodegeneracyjne charakteryzujace się powolnym zanikiem neuronów dopaminergicznych w rejonach mózgu, kontrolujacych ruchy mimowolne, co powoduje upośledzenie motoryki pacjenta. W początkowym stadium choroby chorzy zaczynają odczuwać okresowe drżenie rak, spowolnienie ruchów czy sztywność mięśni. Wraz z progresjac choroby zaburzenia staja się bardziej wyraźne, przyjmując postać znaczacych ograniczeń ruchowych utrudniajacych codzienne funkcjonowanie, pojawiaja się zaburzenia postawy oraz charakterystyczny asymetryczny chód (JANKOVIC 2008). Leczenie farmakologiczne ma charakter objawowy i polega na zwiększonej podaży lewodopy (L-DOPY), która w mózgu jest przekształcana do dopaminy. W terapii parkinsonizmu L-DOPA podawana jest w dużych dawkach w postaci preparatów łaczonych $z$ inhibitorami obwodowej dekarboksylazy aromatycznych L-aminokwasów (karbidopa, benserazyd). L-DOPA jest uważana za złoty standard, jednak charakterystyczna cecha terapii tym lekiem jest to, że $z$ czasem odpowiedź na terapię wyczerpuje się, a dawki trzeba zwiększać. L-DOPA może wchłaniać się wolniej, działać krócej, co powoduje charakterystyczne przerwy w dobrym funkcjonowaniu chorych (tzw. fazy off) i dyskinezy (SHIF i KeMPSTER 1994). W późnym stadium choroby, leczenie farmakologiczne jest mało skuteczne, dochodzi do znacznego 
osłabienia motorycznego, a objawy sa najbardziej wyniszczajace i najgorzej kontrolowane przez leki.

W 1997 r. DANIELE i współaut. opisali przypadek pacjentki w zaawansowanym stadium choroby Parkinsona, której, ze względu na współistniejaca bezsenność, do terapii włączono zolpidem. Paradoksalnie, 30 min po podaniu pierwszej dawki zolpidemu (10 mg) w celu indukcji snu, u pacjentki nie zaobserwowano senności, lecz ustapienie objawów parkinsonowskich (akinezji, sztywności i drżenia spoczynkowego). Efekt zolpidemu utrzymywał się przez około 3 godz., co ściśle koresponduje $z$ właściwościami farmakokinetycznymi zolpidemu i jego krótkim okresem półtrwania (VON MOLTKE i wpsółaut. 1999). Od tej pory zolpidem właczono pacjentce do terapii przeciwparkinsonowskiej, podając jedna tabletkę $10 \mathrm{mg}$ cztery razy dziennie. Podczas 5-letniego okresu terapii zolpidemem, u pacjentki nie zanotowano żadnych działań niepożadanych. Kiedy zolpidem zastapiono jednorazowo innymi lekami nasennymi: triazolamem czy zopiklonem, nie zaobserwowano żadnej poprawy funkcji motorycznych; leki te nie wykazywały efektu przeciwparkinsonowskiego.

Te korzystne efekty terapeutyczne zaobserwowane u pojedynczej osoby, zainspirowały autorów doniesienia do przeprowadzenia pilotażowego badania klinicznego, w którym badano skuteczność zolpidemu w redukowaniu objawów parkinsonizmu (DANIELE i wpsółaut. 1997). Do badania zrekrutowano 10 chorych $z$ choroba Parkinsona, wszystkie leki przeciwparkinsonowskie, które pacjenci przyjmowali odstawiono na czas badania. W celu weryfikacji skuteczności zolpidemu, wykorzystano ujednolicona skalę oceny choroby Parkinsona ( $z$ ang. Unified Parkinson's Disease Rating Scale, UPDRS), która posłużyła do oceny funkcji motorycznych pacjentów przed podaniem leku (poziom wyjściowy; ang. base line) i 1 godz. po podaniu. Autorzy badania zaobserwowali, iż zolpidem spowodował istotna klinicznie poprawę funkcji motorycznych 1 godz. po podaniu, w porównaniu do poziomu wyjściowego. Największą skuteczność zaobserwowano wśród pacjentów będacych w zaawansowanym stadium choroby. Efekt zolpidemu utrzymywał się przez 3h, co jest zwiazanie $z$ jego właściwościami farmakokinetycznymi. Pojedyncza dawka $10 \mathrm{mg}$ zolpidemu nie indukowała dyskinez u żadnego pacjenta, nawet $\mathrm{u}$ tych pacjentów, u których występowały już dyskinezy wywołane terapia lewodopa. Jedynym działaniem niepożądanym jakie odnotowano była senność, która wystapiła u 4 spośród 10 pacjentów. Co ciekawe, efekt senności nie wystąpił u pacjentów w zaawansowanym stadium choroby. Autorzy zasugerowali konieczność przeprowadzenia dalszych badań, uwzględniając niższe dawki zolpidemu, celem określenia efektu przeciwparkinsonowskiego oraz wystapienia potencjalnej senności (DANIEle i wpsółaut. 1997).

W 2000 r. RUZICKA i współaut. opisali przypadek kliniczny 45-letniej pacjentki, u której zdiagnozowano chorobę Parkinsona po raz pierwszy w 1987 r. W 1997 r. pojawiły się u niej fluktuacje motoryczne wywołanie jednoczesnym podawaniem lewodopy. Ze względu na współtowarzyszacą bezsenność, pacjentka otrzymała zolpidem. Przez przypadek pacjentka zaobserwowała poprawę objawów motorycznych, a dyskinezy były mniej nasilone po podaniu 2,5 $\mathrm{mg}$ lub $5 \mathrm{mg}$ zolpidemu. Ze względu na zadziwiajacy efekt terapeutyczny, zolpidem włączono na stałe to terapii, w dawce $5 \mathrm{mg}$ podawanej 6 razy dziennie przez okres 3 lat. Co ciekawe, pacjentka nie odczuwała efektu senności w ciagu dnia przy dawce $5 \mathrm{mg}$, a podczas 3 letniego okresu terapii nie pojawiły się żadne działania niepożądane, nie rozwinęło się zjawisko tolerancji i dawkę $5 \mathrm{mg}$ utrzymano $\mathrm{w}$ trakcie całego okresu terapii.

Podobne przypadki kliniczne zostały opisane przez innych autorów. Dotyczyły pojedynczych pacjentów, a także pilotażowych badań klinicznych $z$ udziałem 10 pacjentów, u których zaobserwowano wyraźną poprawę funkcji motorycznych (DANIELE i współaut. 2016). Raporty dotyczyły mniejszych dawek, tj. $5 \mathrm{mg}$, po których zaobserwowano istotna kliniczna poprawę funkcji motorycznych bez współtowarzyszaccej senności w ciagu dnia.

Powyższe obserwacje zainspirowały badaczy $z$ Uniwersytetu $z$ Aston (Wielka Brytania), którzy w 2018 r. zainicjowali II fazę badań klinicznych (numer badania klinicznego na stronie: ClinicalTrials.gov: NCT03621046). Celem badania była weryfikacja efektu terapeutycznego zolpidemu podawanego w niskich dawkach $(5 \mathrm{mg})$ chorym, u których zdiagnozowano chorobę Parkinsona co najmniej 5 lat temu. Ocena funkcji motorycznych pacjentów została przeprowadzona 1 godz. po podaniu za pomoca ujednoliconej skali oceny choroby Parkinsona (UPDRS), w porównaniu $z$ poziomem wyjściowym (ang. base line). Oceniono również ewentualne reakcje niepożądane. Badanie zostało zakończone w marcu 2020, a wyniki nie zostały jeszcze opublikowane.

Autorzy obserwacji klinicznych zasugerowali mechanizm działania, który częściowo został potwierdzony za pomoca modeli zwierzęcych (DANIELE i współaut. 2016, AssinI i ABERCROMBIE 2018). U zdrowego człowieka istnieje pewna równowaga pomiędzy neurotransmisja dopaminergiczna i GABA-ergiczna 

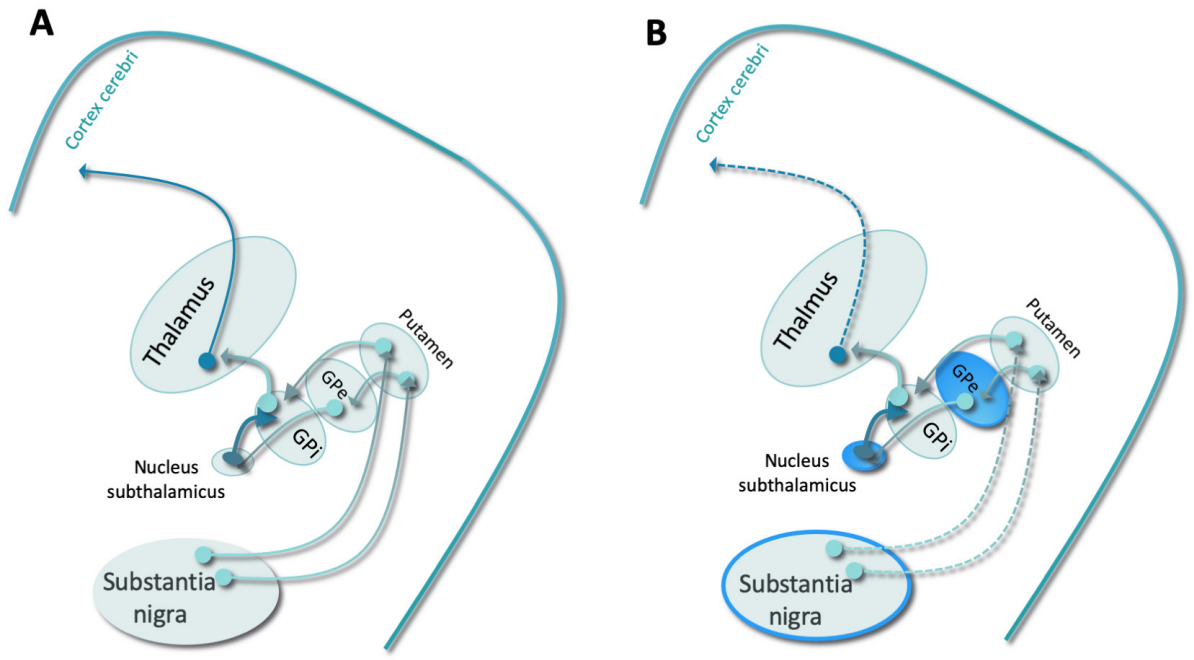

Ryc. 2. Układ struktur kontrolujących ruchy mimowolne u A: zdrowej osoby, B: osoby z choroba Parkinsona.

Cortex cerebri: kora mózgu; Thalamus: wzgórze; Putamen: skorupa; GPe: Globus pallidus; Externus: gałka blada zewnętrzna; GPi: Globus pallidus internus, gałka blada wewnętrzna; Nucleus subthalamicus: jądro niskowzgórzowe; Substancia nigra: istota czarna. Opis w tekście.

a aktywnością struktur mózgu kontrolujących ruchy mimowolne, które funkcjonuja na zasadzie sieci wzajemnych połaczeń (Ryc. 2A). W chorobie Parkinsona obserwujemy degenerację neuronów dopaminergicznych tworzacych szlaki nigrostriatalne, co w efekcie zaburza funkcjonowanie odpowiednich struktur i połaczeń kontrolujacych ruchy mimowolne; między innymi obserwuje się nieprawidłowości w funkcjonowaniu układu GABAergicznego (Ryc. 2B). Śmierć neuronów dopaminergicznych indukuje mechanizmy kompensacyjne, które maja przeciwdziałać powstałemu ubytkowi tak, aby zapewnić stabilność całego systemu. Prace na zwierzętach wykazały, iż po uszkodzeniu części zbitej istoty czarnej (łac. substantia nigra pars compacta) lub jąder prażkowia, zmniejsza się aktywność neuronów GABA-ergicznych w gałce bladej (łac. globus pallidus) i jądrze niskowzgórzowym (łac. nucleus subthalamicus). Zmiany te indukuja kompensacyjny wzrost wrażliwości i gestości receptorów $\alpha 1-G A B A-A$ w tych strukturach. Zolpidem, łączac się $z$ selektywnie $z$ receptorem a1-GABA-A, powoduje nasilenie transmisji GABA-egicznej w wymienionych strukturach, wyrównujacc zaburzona neurotransmisję, co skutkuje natychmiastowa poprawa funkcji motorycznych (DANIELE i współaut. 2016).

Powyższe obserwacje pozwoliły również częściowo wytłumaczyć paradoksalny efekt „ożywienia”, przejawiajacy się szybka poprawą funkcji motorycznych, zamiast senności $u$ pacjentów w zaawansowanym stadium choroby. U tej części pacjentów prawdopodobnie dochodzi do nasilonej up-regulacji
GABA-ergicznej i zwiazanym $z$ tym wzrostem gęstości i wrażliwości receptorów $\alpha 1-$ GABA-A w odpowiednich strukturach (jadrze niskowzgórzowym, gałce bladej wewnętrznej i istocie czarnej siatkowatej) (Ryc. 2B). Dlatego $\mathrm{u}$ pacjentów $\mathrm{z}$ choroba Parkinosna zolpidem wiąże się preferencyjnie w tych strukturach, co powoduje wyrównanie zaburzonej neurotransmisji i poprawę funkcji motorycznych. U zdrowego człowieka nie obserwujemy tych zmian patologicznych, dlatego zolpidem wiąże się preferencyjnie $z$ receptorami a1-GABA-A w innych strukturach mózgu, wywołujac działanie nasenne. U pacjentów $z$ choroba Parkinsona działanie nasenne występuje w dużo wyższych dawkach (jednorazowo 20-30 mg) (DANIELE i współaut. 2016).

\section{WPEYW ZOLPIDEMU NA POPRAWE FUNKCJI POZNAWCZYCH I MOTORYCZNYCH U PACJENTÓW PO PRZEBYTYM UDARZE MÓZGU}

W 2016 r. z grupa badawczą Wydziału Farmaceutycznego Collegium Medicum Uniwersytetu Jagiellońskiego skontaktowała się kobieta informujac, iż zaobserwowała u swojego męża zadziwiająca poprawę objawów neurologicznych będacych skutkiem niedotlenienia mózgu. W 2004 r., po incydencie określanym jako „balet serca” (franc. torsade de pointes) i długiej reanimacji, u męża doszło do niedotlenienia mózgu, w skutek czego zaobserwowano ubytki w płatach czołowych i skroniowych mózgu. Pacjent przebywał w stanie wegetatywnym, po kilku próbach leczenia odzyskał przytomność. Obec- 
nie stan pacjenta jest stabilny, pacjent chodzi i je samodzielnie, zgłasza potrzeby, ale mowa jest bardzo niewyraźna, pacjent cierpi na deficyty pamięci krótkotrwałej. Wyraźnie objawia się u niego stan apatii poudarowej, charakteryzujący się zmniejszoną aktywnością, ogólnym spowolnieniem i biernością. Po podaniu $5 \mathrm{mg}$ zolpidemu pacjent ożywia się, dyskutuje, mowa staje się płynna, chętniej współpracuje $z$ personelem medycznym.

Podobny przypadek opisała AUTRET i współaut. (2013) u 44-letniego pacjenta, który cierpiał na zespół apatii poudarowej po przebytym udarze niedokrwiennym. Pacjent poruszał się tylko w asyście personelu medycznego i cierpiał na niedowład lewej kończyny górnej. Po podaniu $10 \mathrm{mg}$ zolpidemu zespół apatii poudarowej cofał się, zaobserwowano również poprawę motoryki pacjenta. W celu potwierdzenia efektu terapeutycznego autorzy tego przypadku postanowili przeprowadzić podwójnie zaślepiona, kontrolowaną placebo próbę kliniczną. Pacjent losowo otrzymywał zolpidem (jednorazowo $10 \mathrm{mg}$ ) lub placebo. Klinicysta nie wiedzac co otrzymuje pacjent, dokonywał oceny jego stanu za pomoca specjalnej skali oceny zespołu apatii (ang. apathy inventory) oraz skali oceny neuropsychologicznej (ang. behavioural assessment of dysexecutive syndrome). Wyniki analizy jasno wskazały, iż jednorazowe podanie $10 \mathrm{mg}$ zolpidemu spowodowało radykalna poprawę funkcji poznawczych, behawioralnych oraz cofanie się zespołu apatii poudarowej, w porównaniu do placebo. Nie zanotowano u pacjenta senności ani innego działania niepożądanego. Efekt zolpidemu był przejściowy, pojawiał się $30 \mathrm{~min}$ po podaniu i utrzymywał się przez $3 \operatorname{god} z$. Klinicyści wskazali również, że wcześniejsze próby leczenia apatii poudarowej za pomoca leków przeciwdepresyjnych u tego pacjenta były nieskuteczne (AUTRET i współaut. 2013).

$\mathrm{Na}$ przestrzeni ostatnich 15 lat przedstawiono 14 podobnych, pojedynczych raportów klinicznych, w których opisano poprawę funkcji poznawczych u pacjentów po przebytym udarze niedokrwiennym mózgu czy niedotlenieniu mózgu wskutek urazów lub zatrzymania krążenia (SUTTON i ClAUSS 2017). Pojedyncze raporty opisywały zazwyczaj poprawę funkcji motorycznych, odzyskiwanie funkcji mowy, zwiększona komunikację pacjenta czy cofanie się zespołu apatii poudarowej. Pojawiły się również pilotażowe badania kliniczne obejmujace małe grupy pacjentów (3 i 12), u których zaobserwowano poprawę funkcji motorycznych i behawioralnych po jednorazowym podaniu zolpidemu (NyAKale i współaut. 2010). Ponieważ badania te obejmowały małe grupy pacjentów, $Z$ różnymi typami schorzeń: udary, uszkodze- nia, niedotlenienie spowodowane zatrzymaniem krążenia, autorzy doniesień zasugerowali konieczność przeprowadzenia dalszych badań klinicznych, podwójnie zaślepionych, randomizowanych, $z$ udziałem większej liczby pacjentów.

Oczywista konsekwencja tych obserwacji klinicznych były próby wyjaśnienia mechanizmu działania zolpiemu. Do tej pory ukazały się dwie prace eksperymentalne (CLARKSON i współaut. 2010, Hiu i współaut. 2016), które próbowały tłumaczyć wpływ zolpidemu na regresję objawów neurologicznych udaru. Badania te wskazały istotna rolę zaburzonej transmisji GABA-ergicznej w tzw. strefie penumbry, która bezpośrednio otacza rejon martwicy. Udar niedokrwienny mózgu powstaje w wyniku zablokowania przepływu krwi w naczyniu mózgowym. W wyniku niedotlenienia powstaje miejscowa martwica, a tkanka otaczajaca ten obszar to tzw. „rejon penumby", w którym przepływ krwi jest ograniczony. Podczas ostrej fazy udaru, w rejonie penumbry krew docierała w ograniczonej ilości, co spowodowało uruchomienie kaskady procesów patologicznych, obejmujących rozległe zmiany biochemiczne, procesy zapalne, apoptozę, jak również nadmierna aktywację tonicznego prąu GABA-ergicznego. W warunkach fizjologicznych istnieje pewna równowaga pomiędzy synaptyczna transmisja GABA-ergiczna przekazywana przez tzw. synaptyczne receptory GABA-A a toniczną transmisja GABA-ergiczna, która powstaje $\mathrm{w}$ wyniku pobudzenia receptorów ekstrasynaptycznych GABA-A (Ryc. 3A). Receptory synaptyczne zlokalizowane sa wewnattrz synapsy na błonie postsynaptycznej i zbudowane sa $z$ podjednostek: a13ß2-3y1-3. W wyniku aktywacji receptorów synaptycznych powstaje tzw. transmisja synaptyczna (fazowa), która zachodzi bardzo szybko i następuje w wyniku krótkotrwałego nagromadzenia się dużej ilości GABA w szczelinie synaptycznej. Dlatego transmisję synaptyczną możemy porównać do serii krótkich „eksplozji, wybuchów" transmisji GABA-ergicznej. Receptory ekstrasynaptyczne sa zlokalizowane poza obrębem synapsy $i$

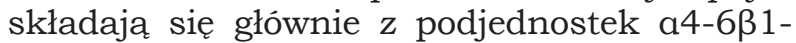
$3 \gamma 2$ i a4-6 $\beta 1-3 \delta$ (BRICKLEY i MODY 2012). Receptory ekstrasynaptyczne doświadczaja stałej i długotrwałej ekspozycji na stosunkowo niskie, ale stałe stężenia GABA, który wydostaje się $z$ szczeliny synaptycznej. Aktywacja receptorów ekstrasynaptycznych uruchamia transmisję toniczna, która występuje spontanicznie i ma charakter powolny. W warunkach fizjologicznych natężenie prądu tonicznego jest regulowane przez wychwyt zwrotny GABA przez transportery dla GABA 
A

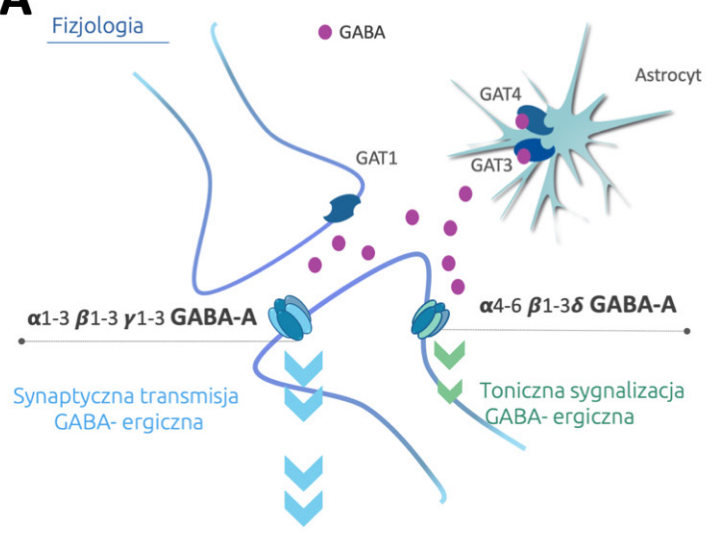

B

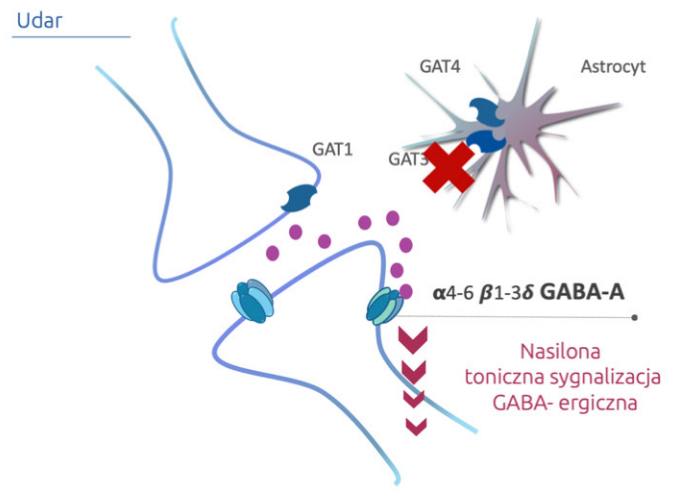

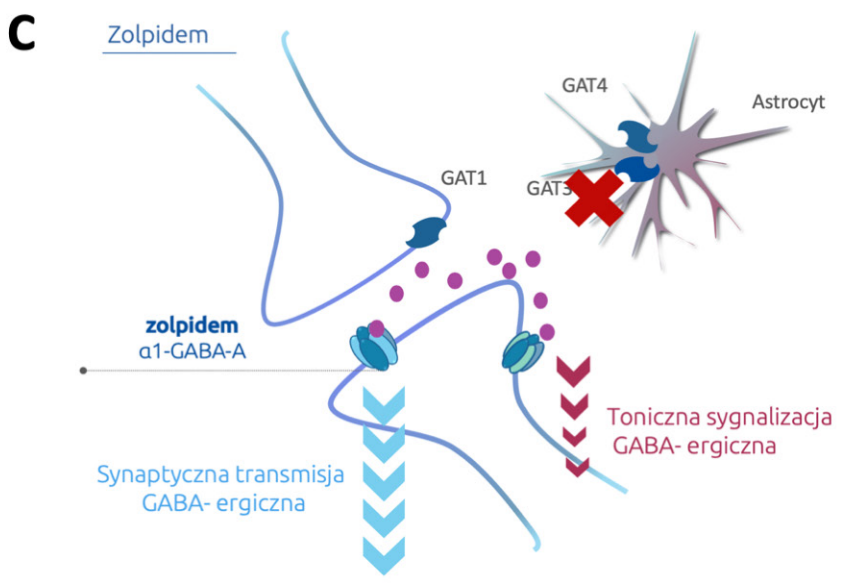

Ryc. 3A. Synaptyczna transmisja GABA-ergiczna (w której pośrednicza receptory synaptyczne a1-3ß13y1-3 GABA-A, zlokalizowane wewnattrz synapsy) oraz toniczna transmisja GABA-ergiczna (przekazy-

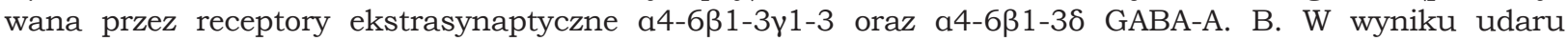
dochodzi do dysfunkcji transporterów GAT, co skutkuje wzmożoną transmisją GABA-ergiczną. C. Zolpidem łaczy się selektywnie $z$ podjednostką a1 GABA-A receptorów synaptycznych i nasila transmisję synaptyczna, co koreluje $z$ poprawą funkcji motorycznych.

(GAT 2/3) zlokalizowane na powierzchni astrocytów (Ryc. 3B).

W skutek udaru, w rejonie penumbry dochodzi do dysfunkcji transporterów GAT. W efekcie nadmiar GABA, który nie został wychwycony przez transportery astrocytalne, zaczyna nadmiernie pobudzać ekstrasynaptyczne receptory GABA-A, co powoduje nasilenie tonicznej transmisji GABA-ergicznej (ClARKSON i współaut. 2010). W przypadku udaru mózgu, nasilona toniczna transmisja GABA-ergiczna koreluje $z$ nasileniem deficytów neurologicznych.

Podobnie jak w przypadku choroby Parkinsona, prace eksperymentalne prowadzone w zwierzęcym modelu udaru mózgu wykazały, iż w rejonie penumbry zaobserwowano zwiększony poziom ekspresji receptorów a1-GABA-A (HIU i współaut. 2016). Dlatego zolpidem, jako selektywny ligand, łaczy się $z$ receptorem a1-GABA-A, nasila fazowa sy- gnalizację GABA, która bezpośrednio koreluje $z$ poprawa funkcji motorycznych u zwierzat doświadczalnych (Ryc. 3C). Autorzy tych prac eksperymentalnych wskazali receptor a1-GABA-A jako obiecujacy cel terapeutyczny dla opracowania nowej generacji leków, które mogłyby poprawiać rekonwalescencję po udarze niedokrwiennym mózg.

\section{OPIS PRZYPADKÓW WYBUDZEŃ ZE STANU WEGETATYWNEGO PO JEDNORAZOWYM PODANIU ZOLPIDEMU}

W 2000 r. Clauss i współaut. opisali przypadek 30-letniego wówczas pacjenta, który przebywał $\mathrm{w}$ stanie wegetatywnym na skutek wypadku samochodowego. Pewnego wieczoru podano mu zolpidem $(10 \mathrm{mg})$, ponieważ pacjent wykazywał oznaki niepokoju i szarpał się w łóżku. Ku zdumieniu obser- 
wujących, po 20 minutach pacjent odzyskał przytomność. Efekt zolidemu był przejściowy, ponieważ okres aktywności pacjenta utrzymywał się przez 3-4 godz., po czym znowu pozostał on w stanie wegetatywnym. Badania technikami tomograficznymi (ang. single-photon emission computed tomography, SPECT) wykonane $\mathrm{u}$ tego pacjenta po podaniu zolpidemu uwidoczniły wyraźna, wzmożoną aktywację obszarów, które były hipoaktywne przed podaniem zolpidemu oraz zwiększona aktywność obszarów korowych mózgu. Ten niezwykły przypadek zainspirował innych badaczy do podjeccia próby podania zolpidemu innym pacjentom, którzy znajdowali się w stanie wegetatywnym. W 2009 r. WHYTE i MYERS opisali swoje doświadczenia $z$ badania klinicznego, gdzie oceniano efekty zolpidemu (10 mg podanego dojelitowo) u 18 pacjentów, którzy znajdowali się w stanie wegetatywnym. Wśród całej grupy, jeden pacjent zareagował pozytywnie na terapię zolpidemem i odzyskał świadomość. Kolejna grupa badawcza opisała wyniki badania SPECT u pacjentów znajdujących się w stanie wegetatywnym (Du i współaut. 2014). Godzinę po podaniu 10 mg zolpidemu przez sondę nosowo-żołąkowa wykazano wzmożoną perfuzję mózgowa oraz zwiększona aktywność metaboliczną w uszkodzonych obszarach mózgu, ale pacjenci nie odzyskali świadomości. Niemniej jednak autorzy tego badania zasugerowali, iż zolpidem może służyć do stopniowego zwiększania aktywności mózgu u pacjentów znajdujących się w stanie wegetatywnym, u których aktywność mózgu jest wyjściowo na niskim poziomie. W 2014 r. CALABRO i współaut. opisali udany przypadek odzyskania przytomności u pacjentki, której podano zolpidem. Początkowo podano niskie dawki $5 \mathrm{mg}$, bez widocznej poprawy. Dopiero, kiedy dawkę zolpidemu zwiększono do $30 \mathrm{mg}$, pacjentka odzyskała pełna świadomość. Autorzy powyższych obserwacji wskazywali na konieczność prowadzenia dalszych badań klinicznych obejmujących szersze grupy chorych, które pozwoliłyby wskazać grupę pacjentów, u których zolpidem mógłby być skuteczny. Do tej pory nie udało się jednoznacznie ustalić mechanizmu działania odpowiedzialnego za efekt odzyskiwania świadomości przez pacjentów. Niektórzy autorzy wiąża ta aktywność $z$ wyrównaniem zaburzonej równowagi pomiędzy transmisja GABA-ergiczna a glutaminianergiczna, ale hipoteza ta nie została potwierdzona w pracach eksperymentalnych (CLAUsS 2010).

\section{PODSUMOWANIE}

Podsumowując, liczne raporty kliniczne wykazały, iż zolpidem przejściowo poprawia zaburzenia neurologiczne, będące wynikiem udaru mózgu lub niedotlenienia, oraz poprawia motorykę pacjentów głównie w zaawanasowanym stadium choroby Parkinsona. Pojawiły się również doniesienia dotyczace odzyskania stanu świadomości u pacjentów w stanie wegetatywnym po jednorazowym podaniu zolpidemu. Zaobserwowane efekty były przejściowe i utrzymywały się przez 3-4 godz., co jest związane $z$ właściwościami farmakokinetycznymi zolpidemu. Dlatego liczni autorzy podkreślaja konieczność opracowania nowych formulacji zolpidemu (np. powolnego uwalniania niskich dawek), które mogłyby być szczególnie pomocne w poprawie zaburzeń neurologicznych. Klinicyści podkreślaja również konieczność przeprowadzenia szerszych badań klinicznych, które pozwoliłyby ocenić skuteczność i określić ewentualne działania niepożąane. Obecnie brakuje danych odnośnie bezpieczeństwa stosowania zolpidemu u subpopulacji pacjentów $z$ zaburzeniami neurologicznymi. U pewnej grupy chorych terapia zolpidemem jest przeciwskazana. Do tej grupy należą pacjenci, u których występuje obturacyjny bezdech senny, ponieważ zolpidem, podobnie jak inne leki GABA-ergiczne, może nasilać bezdech, powodować hipowentylację, niedotlenienie, co w efekcie może zwiększać ryzyko wystapienia kolejnego udaru mózgu (HUANG i współaut. 2013). Niemniej jednak liczne dane kliniczne sugeruja obiecujacy potencjał terapeutyczny zolpidemu, a także innych czassteczek działajacych w oparciu o selektywna modulację receptora a1-GABA-A, w rekonwalescencji po udarze niedokrwiennym mózgu. Szereg efektów klinicznych obserwowanych po podaniu zolpidemu pozostaje jeszcze niewyjasnionych, co przemawia za potrzeba prowadzenia badań o różnej specyfikacji i dalszego rozwijania tego nurtu badawczego.

$$
\text { Streszczenie }
$$

Zolpidem to lek nasenny o budowie niebenzodiazepinowej, który został wprowadzony do praktyki klinicznej na przełomie lat 80. i 90. XX w. W ciagu ostatniej dekady wzbudził szerokie zainteresowanie po opisaniu kilku przypadków klinicznych, dokumentujących regresję neurologicznych objawów udaru, przywracania sprawności motorycznej u pacjentów z choroba Parkinsona czy przypadki wybudzenia ze stanu wegetatywnego. Niniejsza praca opisuje efekty kliniczne zaobserwowane u pojedynczych pacjentów oraz przedstawia efekty zolpidemu ocenione w pilotażowych badaniach klinicznych $z$ udziałem małej grupy chorych. Dotychczasowe obserwacje wskazuja na obiecujacy potencjał terapeutyczny zolpidemu w badaniach klinicznych u subpopulacji chorych cierpiących na różnorodne zaburzenia neurologiczne. Jednak autorzy licznych prac wskazuja na konieczność prowadzenia dalszych badań klinicznych obejmujacych szersze grupy chorych, celem wykazania skuteczności u większej populacji pacjentów. 


\section{LITERATURA}

Arbilla S., Depoortere H., George P., LANGer S. Z., 1985. Pharmacological profile of the imidazopyridine zolpidem at benzodiazepine recep tors and electrocorticogram in rats. Naunyn. Schmiedebergs Arch. Pharmacol. 330, 248251.

ASSINI R., ABERCROMBIE E. D., 2018. Zolpidem ameliorates motor impairments in the unilaterally 6-hydroxydopamine-lesioned rat. Eur. J. Neurosci. 48, 1896-1905

Autret K., ARNOUld A., Mathieu S., Azouvi P., 2013. Transient improvement of poststroke apathy with zolpidem: a single-case, placebo-con trolled double-blind study. BMJ Case Rep. doi: 10.1136/bcr-2012-007816.

BRICKLEY S. G., MODY I., 2012. Extrasynaptic GABAA receptors: Their function in the CNS and implications for disease. Neuron 73, 2334.

CALCATERRA N. E., BARRow J. C., 2014. Classics in chemical neuroscience: diazepam (Valium). ACS Chem. Neurosci. 5, 253-260.

Calabro S., ARICO I., De Salvo S., Conti-Nibal V., BRAMANTI P., 2014. Transient awakening from vegetative state: Is high-dose zolpidem more effective? Psychiatry. Clin. Neurosci. 69, 122-123.

Clarkson A., HuANG B., MacisaAC S., MOdy I., CARMichael T., 2010. Reducing excessive GA$B A-m e d i a t e d$ tonic inhibition promotes functional recovery after stroke. Nature 468, 305-309.

Clauss R. P., 2010. Neurotransmitters in coma, vegetative and minimally conscious states, pharmacological interventions. Med. Hypotheses. 75, 287-290.

Clauss R. P., GUldenpFennig W. M., NEL H.J., SATHEKGE M. M., VenKANNAGARI R. R., 2000. Extraordinary arousal from semi-comatose state on zolpidem: A case report. S. Afr. Med. J. 90, 68-72.

Cotrel C. C., Jeanmart M., Messer N., 1972. Pyrrolo (3,4-b) pyrazine derivatives. Numer patenty US3862149A.

Daniele A., Albanese A., Gainotti G., Gregori B., Bartolomeo P., 1997. Zolpidem in Parkinson's disease. Lancet 349, 1222-1223.

Daniele A., PANZA F., GRECO A., Logroscino G. SERIPA D., 2016. Can a positive allosteric modulation of GABAergic receptors improve motor symptoms in patients with Parkinson's disease? The potential role of zolpidem in the treatment of Parkinson's disease. Parkinsons Dis. 2531812

Du B., Shan A., Zhang Y., Zhong X., Chen D., CAI K., 2014. Zolpidem Arouses Patients in Vegetative State After Brain Injury: Quantitative Evaluation and Indications. Am J Med Sci. 347, 178-182.

Dusza J. P., TOMCUFCIK J., AlbRIGHT D., 1985. [7-(3-disubstituted amino)phenyl]pyrazolo[1,5-a] pyrimidines. Numer patenty US4626538A.

EmA (Europejska Agencja Leków), 2013. Prescribing of zolpidem in the primary care setting in France, Germany and the UK during 2012. EMA/590514/2013/

HARWARD J. L., ClinARD V. B., JIROTEK M. R., LINGERFELD B. H., MuZYK A. J., 2015. Impact of a US Food and Drug Administration Drug
Safety Communication on Zolpidem Dosing: An observational retrospective cohort. Prim Care Companion. CNS Disord. 17, doi: 10.4088/ PCC. $14 \mathrm{~m} 01728$.

Hiu T., Farzampour Z., PaZ J., Wang E., Badgely C., Olson A., Micheva K., WANG G., LEMMENS R., NiSHIYAMA Y., LIANG X., HAMILTON S., O’ROUKe N., SMith J. S., Huguenard J. R., Bliss T. M., STEINBERG G. H., 2016. Enhanced phasic GABA inhibition during the repair phase of stroke: a novel therapeutic target. Brain 139, 468-480.

Huang W. S., Tsai C. H., Lin C. C., Muo C. H., Sung F. C., Chang Y. J., KaO C. H., 2013. Relationship between zolpidem use and stroke risk: A Taiwanese population-based case-control study. J. Clin. Psychiatry 74, 433-438

JAMROŻY A., HABRAT B., BASINSKA-STARZYCKA A., 2009. Uzależnienie od niebenzodiazepinowych leków nasennych: opis dziesięciu przypadków. Alkohol. Narkom. 22, 87-105.

JANKOVIC J., 2008. Parkinson's disease: clinical features and diagnosis. J. Neurol. Neurosurg. Psychiatry 79, 368-376.

KAPLAN J. P., GEORGE P. 1983. Imidazo[1,2-A] pyridine derivatives and their application as pharmaceuticals. Numer patenty US4382938A.

NyaKale N., Clauss, R. C., NEL W., SATHEKGe M., 2010. Clinical and brain SPECT scan response to zolpidem in patients after brain damage. Arzneimittelforschung 60, 177-181.

RUZICKA E., ROTH J., JECH R., BUSEK P., 2000. Subhypnotic doses of zolpidem oppose dopaminergic-induced dyskinesia in Parkinson's disease. Mov Disord. 15, 734-735.

SANNA E., BUSONERO F., TALANI G., CARTA M., Massa F., Peis M., Maciocco E., Biggio G., 2002. Comparison of the effects of zaleplon, zolpidem, and triazolam at various GABA-A receptor subtypes. Eur. J. Pharm. 451, 103110.

ShiF M., Kempster P. A., 1994. Response to L-dopa and evolution of motor fluctuations in the early phase of treatment of Parkinson's disease. Clin. Exp. Neurol. 31, 38-42.

Sigel E., Steinmann M. E., 2012. Structure, function, and modulation of GABA-A

receptors. J. Biol. Chem. 287, 40224-40231.

SutTon J. A., Clauss R. P., 2017. A review of the evidence of zolpidem efficacy in neurological disability after brain damage due to stroke, trauma and hypoxia: a justification of further clinical trials. Brain Inj. 31, 1019-1027.

TERzano M., Rossi M., PAlomba V., SMERIERI A., 2003. New drugs for insomnia: comparative tolerability of zopiclone, zolpidem and zaleplon. Drug Saf. Int. J. Med. Toxicol. Drug Exp. 26, 261-282.

Von MoltKe L., Greenblatt D., Granda B. W., DUAN S. X., GRASSI J. M., VENKATAKRISHNAN K., HARMATZ J. S. SHADER R., 1999. Zolpidem metabolism in vitro: responsible cytochromes, chemical inhibitors, and in vivo correlations. Br. J. Clin. Pharmacol. 48, 89-97.

WhYTE J., MYERS R., 2009. Incidence of clinically significant responses to zolpidem among patients with disorders of consciousness: a preliminary placebo controlled trial. Am. J. Phys. Med. Rehabil. 88, 410-418. 
KOSMOS Vol. 69, 3, 537-545, 2020

\section{MONIKA MARCINKOWSKA}

Department of Medicinal Chemistry, Faculty of Pharmacy, Jagiellonian University Medical College Cracow, 9 Medyczna Str., 30-688 Krakow, E-mail: monika.marcinkowska@uj.edu.pl

\section{OLD HYPNOTIC DRUG AND ITS CLINICAL EFFICACY IN NEUROLOGICAL DISEASES}

\section{Summary}

Zolpidem is a hypnotic drug with a non-benzodiazepine structure, which was introduced into clinical practice at the turn of the 1980s and 1990s. During the last decade, it aroused wide interest after describing several clinical cases documenting the regression of neurological symptoms of stroke, restoration of motor performance in patients with Parkinson's disease or cases of awakening from a vegetative state. This paper describes the clinical effects observed in individual patients and presents the effects of zolpidem assessed in pilot clinical trials involving a small group of patients. The observations to date indicate the promising therapeutic potential of zolpidem in clinical trials in a sub-population of patients suffering from various neurological disorders. However, the authors of numerous studies indicate the need for further clinical trials involving wider groups of patients in order to demonstrate the effectiveness in a larger population of patients.

Key words: GABA-ergic transmission, ischemic stroke, Parkinson's disease, zolpidem 